\title{
A literature review on motivation
}

\author{
Chandra Sekhar • Manoj Patwardhan • \\ Rohit Kr. Singh
}

Published online: 14 November 2013

(C) International Network of Business and Management 2013

\begin{abstract}
Research on motivation has attracted academic and corporate entities over the last two decades. In the present study, authors have reviewed the intense literature to extract all possible dimensions of motivation, having direct and indirect impact on motivation techniques. This has examined the multidimensionality of motivation from the existing literature and present a conceptual framework based on it, and it is experienced that various motivation techniques (discussed in this study) are having a positive impact on both employee satisfaction and the quality of performance in the organization; however, the model needs to be validated using quantitative measures. In order to study the various issues highlighted in this paper related to employee motivation, a large body of literature mainly from different journals have been incorporated. To make the study more current only those studies were included which were published in the last two decades. In past research papers few dimensions of motivation were used to explain the different models motivation theory which has direct influence on employee motivation. The novelty of this study lies in its theoretical framework where authors have made an attempt to come up with a construct having dimensions that directly or indirectly influences employee motivation.
\end{abstract}

\section{Sekhar $(\bowtie)$}

ABV-Indian Institute of Information Technology and Management Gwalior, Room No. 152, BH-3, ABV-IIITM Morena Link Road, Gwalior 474015, Madhya Pradesh, India

e-mail: chandrasekhar0021@gmail.com; chandrasekhar.iiitm@gmail.com

\section{Patwardhan}

ABV-Indian Institute of Information Technology and Management Gwalior, Block C, ABV-IIITM, Gwalior 474015, Madhya Pradesh, India

R. Kr. Singh

ABV-Indian Institute of Information Technology and Management Gwalior, Room No. 05, BH-3, ABV-IIITM Morena Link Road, Gwalior 474015, Madhya Pradesh, India 
Keywords Motivation - Employee performance - Organizational performance $\cdot$ Motivation techniques

\section{Introduction}

The ingredients of motivation lie within all and the internalized drive toward the dominant thought of the moment (Rabby 2001). Motivation directly links to individual performance that gain to organization performance and as a catalyzer for all individual employees working for an organization to enhance their working performance or to complete task in much better way than they usually do. Organization runs because of people working for it, and each person contributes toward achieving the ultimate goal of an organization. Panagiotakopoulos (2013) concluded that factors affecting staff motivation at a period where the financial rewards are kept to the least leads to stimulate employee performance. So, management personnel's responsibility to motivate their employees to work as per the expectation to enhance the organization's performance. Similarly Dysvik and Kuvaas (2010) concluded that intrinsic motivation was the strongest predictor of turnover intention and relationship between mastery-approach goals and turnover intention was only positive for employees, low in intrinsic motivation. The only thing organization needs to do is to give employees with ample resources and platform to do. As per Kuo (2013) a successful organization must combine the strengths and motivations of internal employees and respond to external changes and demands promptly to show the organization's value. In this paper, we have taken various techniques of motivation from existing literature, and managed to make flow of motivation from young-age employees to old-age employees. From organization perspective managers need to understand the flow of motivation, it helps them to create a culture where employees always get motivated to do better. Barney and Steven Elias (2010) found that with extrinsic motivation there exist a significant interaction between job stress, flex time, and country of residence. Leaders know that at the heart of every productive and successful business lies a thriving organizational culture and hardworking people collaborate passionately to produce great results (Gignac and Palmer 2011). In the body of literature, various frameworks are used by the researchers based on theory of motivation, with only few dimensions of motivation.

\section{Literature review}

In a complex and dynamic environment, leader of the organization used to create the environment in which employee feel trusted and are empowered to take decisions in the organization which leads to enhance motivation level of employee and ultimately organizational performance are enhanced. Smith and Rupp (2003) stated that performance is a role of individual motivation; organizational strategy, and structure and resistance to change, is an empirical role relating motivation in the organization. Likewise, Luthans and Stajkovic (1999) concluded that advancement 
of human resources through rewards, monetary incentives, and organizational behavior modification has generated a large volume of debate in the human resource and sales performance field. According to Orpen (1997) better the relationship between mentors and mentees in the formal mentoring program, the more mentees are motivated to work hard and committed to their organization. Likewise, Malina and Selto (2001) conducted a case study in one corporate setting by using balance score card (BSC) method and found out that organizational outcomes would be greater if employees are provided with positive motivation. The establishment of operations-based targets will help the provision of strategic feedback by allowing the evaluation of actual performance against the operations-based targets. Goaldirected behavior and strategic feedback are expected to enhance organizational performance (Chenhall 2005). Kunz and Pfaff (2002) stated no substantive reason to fear an undermining effect of extrinsic rewards on intrinsic motivation. Decoene and Bruggeman (2006) in their study developed and illustrated a model of the relationship between strategic alignment, motivation and organizational performance in a BSC context and find that effective strategic alignment empowers and motivates working executives. Leaders motivate people to follow a participative design of work in which they are responsible and get it together, which make them responsible for their performance. Aguinis et al. (2013) stated that monetary rewards can be a very powerful determinant of employee motivation and achievement which, in turn, can advance to important returns in terms of firmlevel performance. Garg and Rastogi (2006) identified the key issues of job design research and practice to motivate employees' performance and concluded that a dynamic managerial learning framework is required to enhance employees' performance to meet global challenges. Vuori and Okkonen (2012) stated that motivation helps to share knowledge through an intra-organizational social media platform which can help the organization to reach its goals and objectives. Den and Verburg (2004) found the impact of high performing work systems, also called human resource practices, on perceptual measures of firm performance. Ashmos and Duchon (2000) recognizes that employees have both a mind and a spirit and seek to find meaning and purpose in their work, and an aspiration to be part of a community, hence making their jobs worthwhile and motivating them to do at a high level with a view to personal and social development.

\section{Methodology}

The primary objective to write this review is to highlight the flow of motivation and reveals what motivation technique works more efficiently in different stages of life. This study provides useful managerial implication for employee motivation in an organization. The dimensions are made fit into a model that can benefit organization to enhance their performance; however, the model needs to validate through case study or quantitative study. To study the various issues highlighted in this study related to employee motivation, this study reviews a large body of literature mainly in different journals. Once all the issues have been identified, each issue is used as a keyword to search the relevant literature. To make the study more current only those 
Table 1 Article or review published on motivation

a Current year and it's still continuing publication

\begin{tabular}{clc}
\hline Year & $\begin{array}{l}\text { No. of article or review } \\
\text { published on motivation }\end{array}$ & $\begin{array}{l}\text { \% increase } \\
\text { in publication }\end{array}$ \\
\hline 1990 & 1,549 & - \\
1991 & 1,554 & 0.322 \\
1992 & 1,603 & 3.15 \\
1993 & 1,685 & 5.11 \\
1994 & 2,027 & 20.29 \\
1995 & 2,064 & 1.82 \\
1996 & 2,794 & 35.36 \\
1997 & 2,994 & 7.15 \\
1998 & 3,041 & 1.56 \\
1999 & 3,187 & 4.80 \\
2000 & 3,412 & 7.05 \\
2001 & 3,580 & 4.92 \\
2002 & 3,995 & 11.59 \\
2003 & 4,643 & 16.22 \\
2004 & 5,125 & 10.38 \\
2005 & 5,878 & 14.63 \\
2006 & 6,429 & 9.37 \\
2007 & 6,943 & 7.99 \\
2008 & 7,585 & 9.24 \\
2009 & 8,501 & 12.07 \\
2010 & 9,173 & 7.90 \\
2011 & 9,861 & 7.50 \\
2012 & 10,679 & 8.29 \\
$2013^{\mathrm{a}}$ & 6,858 & Still continuing \\
\hline & &
\end{tabular}

studies are included which are published in the last two decades, while priority is given to studies which are published in the last decade. Table 1 shows that the number of articles or reviews published on motivation in the last two decades (Table 2).

\section{Dimensions of motivation}

Training

Training refers to "the systematic accretion of skills, command, concepts or mindset leads to improve performance" (Lazazzara and Bombelli 2011). Baldwin et al. (1991) indicates that individuals with higher pre-training motivation on the basis of their willingness to attend training have greater learning outcomes as compared to individuals heaving lower pre-training motivation. Commeiras et al. (2013) point out that traineeship is continuing to grow. In business, context training basically refers to action of teaching employees and providing proper knowledge 


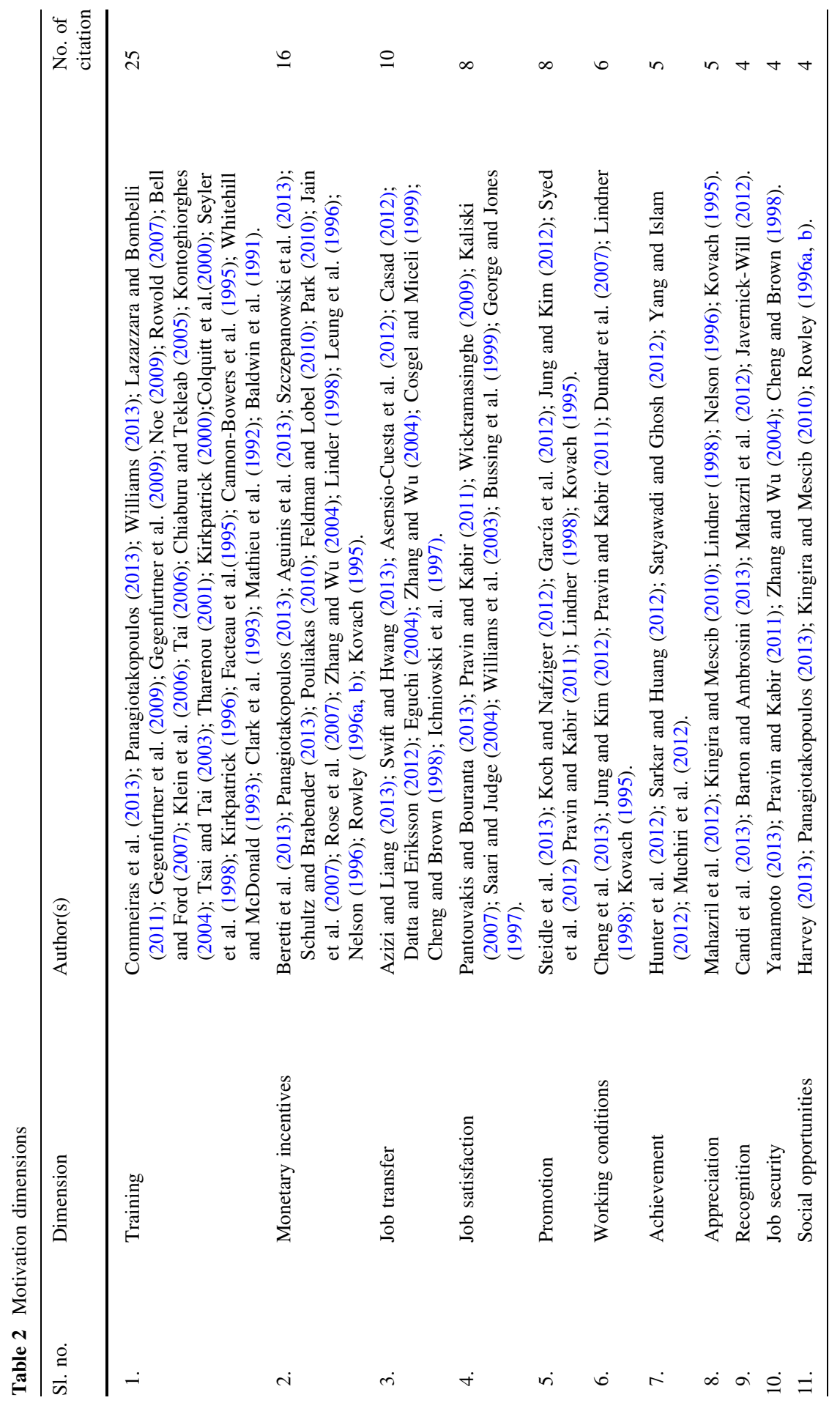


and skills to make themselves job fit as well as organization fit. Training teaches employees how to work and enhance their skills, hence motivate them to achieve the common goal of organization as well as of employee. In the today's competitive world, every organization wants to achieve competitive edge over their competitors and be impossible to achieve without employee involvement, which forces management to motivate their employees by different means.

\section{Monetary incentives}

As summarized by Park (2010), monetary incentive acts as a stimulus for greater action and inculcates zeal and enthusiasm toward work, it helps an employee in recognition of achievement. Likewise, Beretti et al. (2013) discussed that monetary incentives used to build a positive environment and maintain a job interest, which is consistent among the employee and offer a spur or zeal in the employees for better performance. For reason, monetary incentive motivate employees and enhance commitment in work performance, and psychologically satisfy a person and leads to job satisfaction, and shape the behavior or outlook of subordinate toward work in the organization.

\section{Job transfer}

The work of Azizi and Liang (2013) indicated that workforce flexibility can be achieved by cross-training and improved via job rotation. In the same way, Eguchi (2004) concluded that job transfer plays a significant role in preventing workers from performing influence activities for private help. As summarized by AsensioCuesta et al. (2012) job rotation provides benefits to both workers and management in an organization and prevents musculoskeletal disorders, cast out fatigue and increases job satisfaction and morale. As a result, job transfer gives the opportunity to learn multiple skills and outlooks to the workers. It avoids the dullness caused by monotonous jobs and simultaneously brings smoothness in technological job with the help of handling different circumstances at different levels and it leads to effective learning of many aspects in the organization.

Job satisfaction

In (2011), Parvin and Kabir studied the tested factors affecting job satisfaction for pharmaceutical companies and described job satisfaction as how content an individual is with his or her job, and viewed job satisfaction is not the same as motivation, although clearly linked. Similarly, Pantouvakis and Bouranta (2013) indicated job satisfaction as a consequence of physical features and as an antecedent of interactive features. Wickramasinghe (2009) investigated that gender and tenure are significant in job satisfaction measurement. So here it can be said that job satisfaction is often determined by how well outcome meet or exceed expectations. For example, a good work environment and good work conditions can increase employee job satisfaction and the employees will try to give their best which can increase the employee work performance. 


\section{Promotion}

A study by García et al. (2012) identified that perceptions of promotion systems affect organizational justice and job satisfaction. Likewise, Koch and Nafziger (2012) specified that promotions are desirable for most employees, only because they work harder to compensate for their "incompetence." As a result, promotion at regular interval of time has an optimistic approach behind and they are generally given to satisfy the psychological requirements of employees in the organization.

\section{Achievement}

The work of Hunter et al. (2012) defines that achievement is a unique and specialized form of organizational performance. As per Satyawadi and Ghosh (2012), employees are motivated to a greater extent by achievement and selfcontrol. Now this can be understood: an employee who is achievement motivated seeks achievement, bringing realistic but challenging goals, and betterment in the job. There is a strong need for feedback from the higher officials in the organization as to achievement and progress, and a need for a sense of attainment.

\section{Working conditions}

In (2012), Jung and Kim stated that good work environment and good work conditions can increase employee job satisfaction and an employee organizational commitment. So the employees will try to give their best which can increase the employee work performance. Similarly, Cheng et al. (2013) concluded that there were evidences of moderating effects of age on the associations between psychosocial work conditions and health. Now the importance and the need of working condition is so describing or defining the physical environment by identifying those elements or dimensions of the physical environment. Employees having poor working conditions will only provoke negative performance, since their jobs are mentally and physically demanding, they need good working conditions.

\section{Appreciation}

A study by Mahazril et al. (2012) organizations had the duty to appreciate the employee from time to time and offer other form of benefits such as payment, which will help in employee motivation. Likewise, Kingira and Mescib (2010) define appreciation as the abstract of immaterial incentives; "employees giving immaterial incentives (appreciation, respect etc.) as much as materiel incentives with working department" shows employees do not agree with this behavioral statement. With this result, it can be stated that employees being employed in different parts can take their different opinions at different levels. Among the variable of responsibility and being appreciated, it is understood that "success of employers always be appreciated with education." The more effective quality and practicality of education employees had, the more contribution they will have to businesses. 
Job security

As per Yamamoto (2013) if an employee perceives they will be getting rewards for good work and their job is a secured one, the performance will automatically be better. Similarly, Zhang and Wu (2004) indicated that with Job security, an employee gets confident with the future career and they put their most efforts to achieve the objectives of the organization. So we can say job satisfaction is the most influential tool of motivation and put the employee very far off from mental tension and he gives his best to the organization, ultimately it leads to profit maximization.

\section{Recognition}

According to Candi et al. (2013), a growing recognition of the opportunities of innovation is through experience staging. Mahazril et al. (2012) concluded that rewards and recognition and communication may motivate them to work. Recognition enhances the level of productivity and performance at job whether it is a first time performance or a repeated action at the job in a progressive way and ultimately reinforces the behavior of employee.

\section{Social opportunities}

In (2013), Harvey indicated that an employee is accepted as part of the social group or team. Most staff has an acute need that their contribution is worthwhile, appreciated, and acknowledged. Organizations need to look beyond the traditional economic incentives of career opportunities and salaries to other social and lifestyle factors outside the workplace. Similarly, Kingira and Mescib (2010) concluded that, different opinions between the employees in terms of behavioral statements which can be "Social opportunities providing at the highest level with working period leads the employee to achieve their goals of the organization." Therefore, a social opportunity for the employee is used to boost their motivation level and ultimately helps in achieving the goals and objectives of the organization.

Figure 1 explains how motivation works in different stages of life, and motivation dimension plays a vital role in enhancing individual performance in different stages of life of human being. In the developed and developing nations around the world people experiencing the phenomenon of population aging i.e., participation of worker in their late career stage is low in the labor market. Levinson's (1986) life stage model pointed out that adult life is characterized by a consecution of stages, such as early, middle, and late career stage, divided into various sub-stages and concerned with career development (comparable to the career stage model of Super (1984)). Here we have considered early career stage between 20 and 40; middle career stages between 40 and 54, and late career stage 55 and above. In an effort to set a threshold to define the older worker category, as anyone over age 55 (Finkelstein et al. 1995; Koc-Menard 2009).

In the early and middle stage of life, money is important to goal setting because offering such incentives bring person being more willing to expand effort to meet a given goal level than not offering the incentives. Given the willingness to expand 
Flow of Motivation

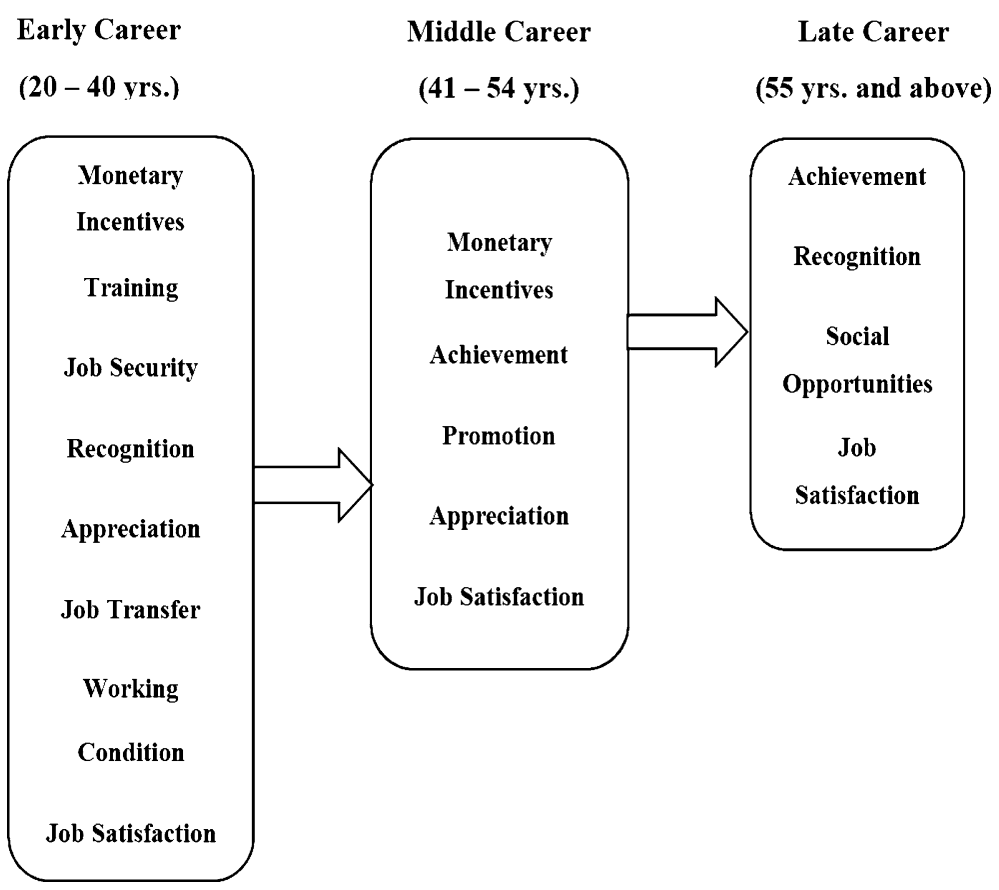

Fig. 1 Flow of motivation

effort, a goal tells the individual during different career stages where to expand effort, how much effort to exert, and how long to exert the effort. For example, younger employees early in their careers may have a propensity for higher immediate compensation and benefits, such as fully paid family medical plans or maternity/paternity leaves; because employees in later career stages might prefer stock options or most company contributions to their retirement plans. Wiley (1997) concluded that good pay is an important motivator regardless of age.

Figure 2 explains how motivation dimensions influence individual and organization performance. In this competitive environment, organizations works harder to integrate its workforce and to keep the coordination among employees to enhance the working as well as employee productivity. The positive impact of motivation works toward enhancing individual responsiveness toward work. Individual enhanced responsiveness help organization working that directly links toward increase in profit and increase in organization responsiveness. Customer will be more satisfied if organization shows fast response toward his/her queries and if organization takes responsibility to fulfill his demand.

If we talk the motivation dimension that enhances organization performance, training used to enhance the skills, efficiency, and knowledge of employees for doing a particular job during their earlier career stage because it familiarizes them with the organizations goals, rules, and regulations and the working conditions in 


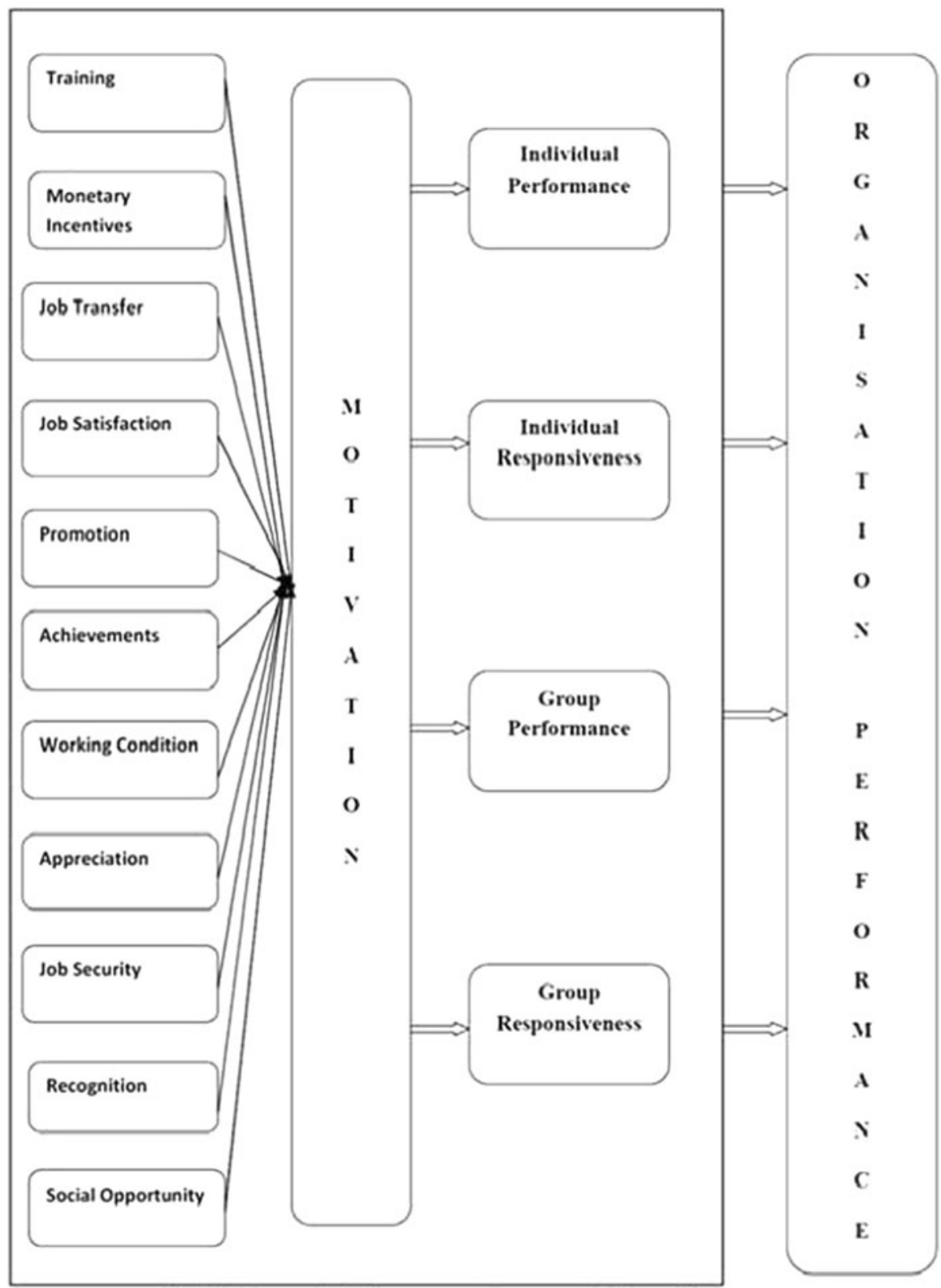

Fig. 2 Theoretical construct of research dimensions

one hand since updates and amendments take place in technology, purchasing a new equipment, changes in technique of production, and computer impartment. The employees are trained for use of new equipments and work methods. Training molds the thinking of employees and leads to quality performance of employees. Supervisors believe that older workers are less motivated to learn, less flexible, and 
do not want to take part in training programs. So, companies do not invest in training or development opportunities for older people. In turn, older workers become less self-confident due to the lack of support in terms of training and their skills rapidly become outdated (Maurer 2001; Van Vianen et al. 2011).

Giving a job security to an employee makes him more responsible toward job. Job security can be explained as, affirmation that an employee has for the continuity of gainful employment for his or her job. It is more essential for younger employee during different career stages of life (job) because it arises from the terms of contract of employment, labor legislation that results in prevention of arbitrary termination, layoffs, and lockout. Likewise, Pravin and Kabir (2011) indicated that with job security in pharmaceutical companies employee is "neither happy nor unhappy" and hence influence job satisfaction in pharmaceutical companies. Job security has been considered from several theoretical perspectives, including as a motivational precursor to job performance.

Employee recognition is used to fulfill the inherent need to appreciate as well as work to be validated by the employee contribution. During the early and later stage of life of the employee, the most important tool to motivate the employee by recognizing positive behavior from employees means that those desired behaviors that drive business success will be reciprocated. Recognition is essential to an outstanding workplace because people want to be respected and valued for their contribution. Recognizing employee for their good work sends an extremely powerful message to the recipient, their work team, and other employees through formal and informal communication channels. Employee recognition is a dynamic communication technique to improve employee performance which leads to enhance organizational performance.

In an organization, it is important to make the employees valued and appreciated, because of which they get motivated and they work harder and be more loyal toward the organization. During the early and middle career stage of the job employee want more appreciation from his next boss in the organization. Many ways of appreciating employee are news for companies looking for inexpensive ways to show appreciation to employees who made an appreciative effort, to thank employees several times a week, often through notes mailed to their homes and admits an employee-of-the-month program, the least time-consuming way to make sure his staff continued to appreciate.

In an organization employees have the opportunity to transfer to another job if they are moving or have the want to switch occupations. It brings positive energy among the early career stage employee to work in a new environment, which gives workers the opportunity to learn multiple skills and outlooks. When employees continue working at the same tasks for an extended time, they are likely to build tight relationships with particular individuals and companies, which can yield help to the employees, and to the organization.

In the early stage of the employee, they used to seek the working environment and aspects of an employee's terms and conditions of employment. This includes the employee payment, organization of work, and work activities; training, skills, and employability; amenities, physical environment, health, safety, and well-being; and working time and work-life balance. These used to motivate the employee to do 
better and achieve the organizational goals and objectives. Changes in working conditions and other aspects of the employment relationship can generate serious industrial relations problems.

Williams et al. (2003) argues that the job satisfaction works toward making good relationships with staff and colleagues, control of time off, enough resources, and bring autonomy for employee in the organization. It is essential in the stages of employment i.e., early, middle, and late career stage of life because it brings any combination of physiological, psychological, satisfaction that invokes a person truthfully to say I am satisfied with my current job and it leads to employee motivation to achieve goals of the organization. Job satisfaction refers doing a job one enjoys, and being rewarded for one's accomplishment. It is the key ingredient that leads to recognition, income, promotion, and the achievement of other goals that lead to a feeling of fulfillment of the desired goals and objectives (Kaliski 2007).

In the middle and late career stages of their employment, employees have an opportunity to showcase their achievements with pride. Employees work in organizations not just to make a living, but to make a life. It encourages heightened ownership at work. Tangible benefits (salary) and intangible benefits (achievements of the knowledge) and other perks are necessary to engage employees, and motivate them to do their personal best. Mehta et al. (2000) pointed out that four most highly ranked rewards for sales managers in the late career stage have mean values that exceed 6.0, which includes achievement of market goals, retaining respect of salespeople, opportunities for promotion, and bonus.

A motivated and dedicated employee in the middle career stage of their job in the organization is an asset for any organization and proves instrumental in building a high-performance culture that drives organizational advancement. Promotion is always employee's ultimate wish for the service rendered by him in the organization and this is the only way for an employee career development. Promotion is the ultimate motivating for any employee because it moves employee forward in hierarchy of concern organization added with other responsibility, higher respect, honors, with increase in grade pay and allowances. It stimulates self-development and creates interest in the job in one hand and minimizes discontent and unrest.

In the late career stage of their employment social opportunities for employees to get involved in leveraging the core competencies of the organization to create business value and positive social change can increase employee motivation and job satisfaction and help workers to more effectively manage job stress. This can lead to positive gains for the organization by enhancing organizational effectiveness and improving work quality, as well as by helping the organization attract and keep topquality employees, which can bring growth and development to the organizations and can improve the quality of their employees' work experience and realize the benefits of developing workers to their full potential.

\section{Concluding remarks}

Motivation works as a catalyzer for individual employees working for an organization to enhance their working performance or to complete task in much 
better way than they usually do. In this paper, authors identified the key motivation techniques from existing literature and linked it through organization performance. These motivation techniques has long been acknowledged as an important personnel work with the potential to improve employee motivation and hence performance, and to deliver management with the control needed to achieve organizational objectives. Authors made flow of motivation from early career motivation techniques to late career motivation techniques and reached on a conclusion: if employees are provided with right motivation technique at right time, their morale and confidence goes up and had a direct positive impact in individual performance and organizational performance. It is indicative of the above discussion, most of the motivation dimensions viz. training, monetary incentives, promotion, and working conditions has been met and for reason the efforts made to motivate are bound to succeed. This conclusion is built on the emphasis made by earlier researchers to motivate people, organizations need to first have the baseline in place; in the absence of the baseline, motivation is not possible to achieve. The study has shown success in intrinsic motivators and extrinsic motivators to improve performance in the organization.

The major limitation of this study is that the proposed framework is designed on basis of extensive literature review and so needs to be confirmed using quantitative measures. This framework is not been implemented in specific industry, due to its generality in nature. Although extensive research is reviewed and every possible dimensions of motivation are studied, it cannot be stated explicitly that these dimensions will be able to create the baseline which will motivate the employees through the motivators. Thus, they create a dilemma as to whether these motivation dimensions are enough to create a solid baseline which has an impact on the motivators.

\section{References}

Aguinis, H., Joo, H., \& Gottfredson, R. K. (2013). What monetary rewards can and cannot do: How to show employees the money. Business Horizons, 56(2), 241-249.

Asensio-Cuesta, S., Diego-Mas, J. A., Canós-Darós, L., \& Andrés-Romano, C. (2012). A genetic algorithm for the design of job rotation schedules considering ergonomic and competence criteria. International Journal of Advanced Manufacturing Technology, 60(9-12), 1161-1174.

Ashmos, D. P., \& Duchon, D. (2000). Spirituality at work: A conceptualization and measure. Journal of Management Inquiry, 9(2), 134-145.

Azizi, N., \& Liang, M. (2013). An integrated approach to worker assignment, workforce flexibility acquisition, and task rotation. Journal of the Operational Research Society, 64(2), 260-275.

Baldwin, T. T., Magjuka, R. J., \& Loher, B. (1991). The perils of participation: Effects of the choice of training on trainee motivation and learning. Personnel Psychology, 44(1), 51-65.

Barney, E. C., \& Steven Elias, M. S. (2010). Flex-time as a moderator of the job stress-work motivation relationship: A three nation investigation. Personnel Review, 39(4), 487-502.

Barton, L. C., \& Ambrosini, V. (2013). The moderating effect of organizational change cynicism on middle manager strategy commitment. International Journal of Human Resource Management, 24(4), 721-746.

Bell, B. S., \& Ford, J. K. (2007). Reactions to skill assessment: The forgotten factor in explaining motivation to learn. Human Resource Development Quarterly, 18(1), 33-62.

Beretti, A., Figuières, C., \& Grolleau, G. (2013). Using money to motivate both 'saints' and 'sinners': A field experiment on motivational crowding-out. Kyklos, 66(1), 63-77. 
Bussing, A. T., Bissels, T., Fuchs, V., \& Perrar, K.-M. (1999). A dynamic model of work satisfaction: Qualitative approaches. Human Relations, 52(8), 999-1028.

Candi, M., Beltagui, A., \& Riedel, J. C. K. H. (2013). Innovation through experience staging: Motives and outcomes. Journal of Product Innovation Management, 30(2), 279-297.

Cannon-Bowers, J. A., Salas, E., Tannenbaum, S. I., \& Mathieu, J. E. (1995). Toward theoretically based principles of training effectiveness: A model and initial empirical investigation. Military Psychology, 7(3), 141-164.

Casad, S. (2012). Implications of job rotation literature for performance improvement practitioners. Performance Improvement Quarterly, 25(2), 27-41.

Cheng, A., \& Brown, A. (1998). HRM strategies and labor turnover in the hotel industry: A comparative study of Australia and Singapore. International journal of human resource management, 9(1), 136-154.

Cheng, Y., Chen, I.-S., Chen, C.-J., Burr, H., \& Hasselhorn, H. M. (2013). The influence of age on the distribution of self-rated health, burnout and their associations with psychosocial work conditions. Journal of Psychosomatic Research, 74(3), 213-220.

Chenhall, R. H. (2005). Integrative strategic performance measurement systems, strategic alignment of manufacturing, learning and strategic outcomes: An exploratory study. Accounting, Organizations and Society, 30(5), 395-422.

Chiaburu, D. S., \& Tekleab, A. G. (2005). Individual and contextual influences on multiple dimensions of training effectiveness. Journal of European Industrial Training, 29(8), 604-626.

Clark, C. S., Dobbins, G. H., \& Ladd, R. T. (1993). Exploratory field study of training motivation: Influence of involvement, credibility, and transfer climate. Group Organization Management, 18(3), 292-307.

Colquitt, J. A., LePine, J. A., \& Noe, R. A. (2000). Toward an integrative theory of training motivation: A meta-analytic path analysis of 20 years of research. Journal of Applied Psychology, 85(5), 678-707.

Commeiras, N., Loubes, A., \& Bories, A. (2013). Identification of organizational socialization tactics: The case of sales and marketing trainees in higher education. European Management Journal, 31(2), 164-178.

Cosgel, M., \& Miceli, T. (1999). Job rotation: Cost, benefits, and stylized facts. Journal of Institutional and Theoretical Economics, 155, 301-320.

Datta, G. N., \& Eriksson, T. (2012). HRM practices and the within-firm gender wage gap. British Journal of Industrial Relations, 50(3), 554-580.

Decoene, V., \& Bruggeman, W. (2006). Strategic alignment and middle-level managers' motivation in a balanced scorecard setting. International Journal of Operations and Production Management, 26(4), 429-448.

Den, H. D. N., \& Verburg, R. M. (2004). High performance work systems, organizational culture and firm performance. Human Resource Management Journal, 14, 55-78.

Dundar, S., Ozutku, H., \& Taşpınar, F. (2007). İcsel ve dışsal motivasyon araclarının işgorenlerin motivasyonu uzerindeki etkisi: ampirik bir inceleme. Ticaret ve Turizm Eğitim Fakultesi Dergisi, 2, 105-119.

Dysvik, A., \& Kuvaas, B. (2010). Exploring the relative and combined influence of mastery-approach goals and work intrinsic motivation on employee turnover intention. Personnel Review, 39(5), 622-638.

Eguchi, K. (2004). Job transfer and influence activities. Journal of Economic Behavior and Organization, 56, 187-197.

Facteau, J. D., Dobbins, G. H., Russell, J. E., Ladd, R. T., \& Kudisch, J. D. (1995). The influence of general perceptions of the training environment on pre-training motivation and perceived training transfer. Journal of Management, 21(1), 1-25.

Feldman, Y., \& Lobel, O. (2010). The incentives matrix: The comparative effectiveness of rewards, liabilities, duties, and protections for reporting illegality. Texas Law Review, 88(6), 1151-1211.

Finkelstein, L. M., Burke, M. J., \& Raju, N. S. (1995). Age discrimination in simulated employment contexts: An integrative analysis. Journal of Applied Psychology, 80(6), 652-663.

García, I. A. L., Moscoso, S., \& Ramos, V. P. J. (2012). Reactions to the Fairness of Promotion Methods: Procedural justice and job satisfaction. International Journal of Selection and Assessment, 20(4), 394-403.

Garg, P., \& Rastogi, R. (2006). New model of job design: Motivating employees' performance. Journal of Management Development, 25(6), 572-587. 
Gegenfurtner, A., Festner, D., Gallenberger, W., Lehtinen, E., \& Gruber, H. (2009a). Predicting autonomous and controlled motivation to transfer training. International Journal of Training and Development, 13(2), 124-138.

Gegenfurtner, A., Veermans, K., Festiner, D., \& Gruber, H. (2009b). Motivation to transfer training: An integrative literature review. Human Resource Development Review, 8(3), 403-423.

George, J. M., \& Jones, G. R. (1997). Organizational spontaneity in context. Human Performance, 10(1), $153-170$.

Gignac, G. E., \& Palmer, B. R. (2011). The genos employee motivation assessment. Industrial and Commercial Training, 43(2), 79-87.

Harvey, W. (2013). Victory can be yours in the global war for talent: Social factors and lifestyle help to attract top employees. Human Resource Management International Digest, 21(1), 37-40.

Hunter, S. T., Cushenbery, L., \& Friedrich, T. (2012). Hiring an innovative workforce: A necessary yet uniquely challenging endeavor. Human Resource Management Review, 22(4), 303-322.

Ichniowski, C., Shaw, K., \& Prennushi, G. (1997). The effects of human resource management practices on productivity: A study of steel finishing lines. American Economic Review, 87, 291-313.

Jain K. K., Jabeen F., Mishra, V., and Gupta, N. (2007). International Review of Business Research Papers, 13(5), 193-208.

Javernick-Will, A. (2012). Motivating knowledge sharing in engineering and construction organizations: Power of social motivations. Journal of Management in Engineering, 28(2), 193-202.

Jung, J., \& Kim, Y. (2012). Causes of newspaper firm employee burnout in Korea and its impact on organizational commitment and turnover intention. International Journal of Human Resource Management, 23(17), 3636-3651.

Kaliski, B. S. (2007). Encyclopedia of business and finance (2nd ed., p. 446). Detroit: Thompson Gale.

Kingira, \& Mescib, M. (2010). Factors that affect hotel employs motivation the case of bodrum. Serbian Journal of Management, 5(1), 59-76.

Kirkpatrick, D. (1996). Great ideas revisited: Revisiting Kirkpatrick's four-level model. Training and Development, 50(1), 54-67.

Kirkpatrick, D. L. (2000). Evaluating training programs: The four levels', In G. M. Piskurich, P. Beckschi, \& B. Hall (Eds.), The ASTD handbook of training design and delivery (pp. 133-146). New York, NY: McGraw-Hill.

Klein, H. J., Noe, R. A., \& Wang, C. W. (2006). Motivation to learn and course outcomes: The impact of delivery mode, learning goal orientation, and perceived barriers and enablers. Personnel Psychology, 59(3), 665-702.

Koch, A. K., \& Nafziger, J. (2012). Job assignments under moral hazard: The Peter principle revisited. Journal of Economics and Management Strategy, 21(4), 1029-1059.

Koc-Menard, S. (2009). Training strategies for an aging workforce. Industrial and Commercial Training, 41(6), 334-348.

Kontoghiorghes, C. (2004). Reconceptualising the learning transfer conceptual framework: Empirical validation of a new systemic model. International Journal of Training and Development, 8(3), 210-220.

Kovach, K. A. (1995). Employee motivation: Addressing a crucial factor in your organization's performance. Employee Relations Today, 22(2), 93-105.

Kunz, A. H., \& Pfaff, D. (2002). Agency theory, performance evaluation, and the hypothetical construct of intrinsic motivation. Accounting, Organizations and Society, 27(3), 275-295.

Kuo, Y. K. (2013). Organizational commitment in an intense competition environment. Industrial Management and Data Systems, 113(1), 39-56.

Lazazzara, A., \& Bombelli, C. M. (2011). HRM practices for an ageing Italian workforce: The role of training. Journal of European Industrial Training, 35(8), 808-825.

Leung, K., Smith, P. B., Wang, Z., \& Sun, H. (1996). Job satisfaction in joint venture hotels in China: An organizational justice analysis. Journal of International Business Studies, 27(5), 947-962.

Levinson, D. J. (1986). A conception of adult development. American Psychologist, 41(1), 3-13.

Linder, J. R. (1998). Understanding employee motivation. Journal of Extension, 36(3), $28-43$.

Luthans, F., \& Stajkovic, A. D. (1999). Reinforce for performance: The need to go beyond pay and even rewards. The academy of management executive, 13(2), 49-57.

Mahazril, A. Y., Zuraini, Y. Z., Hafizah, H. A. K., Aminuddin, A., Zakaria, Z., Noordin, N., et al. (2012). Work motivation among Malaysian public servants. Asian Social Science, 8(12), 238-242.

Malina, M. A., \& Selto, F. H. (2001). Communicating and controlling strategy: An empirical study of the effectiveness of the balanced scorecard. Journal of Management Accounting Research, 13, 47-90. 
Mathieu, J. E., Tannenbaum, S. I., \& Salas, E. (1992). Influences of individual and situational characteristic on measures of training effectiveness. Academy of Management Journal, 35(4), $828-847$.

Maurer, T. J. (2001). Career-relevant learning and development, worker age, and beliefs about selfefficacy for development. Journal of Management, 27, 123-140.

Mehta, R., Rolph, E. A., \& Alan, J. D. (2000). The perceived importance of sales managers' rewards: A career stage perspective. Journal of Business and Industrial Marketing, 15(7), 507-524.

Muchiri, M. K., Cooksey, R. W., \& Walumbwa, F. O. (2012). Transformational and social processes of leadership as predictors of organizational outcomes. Leadership and Organization Development Journal, 33(7), 662-683.

Nelson, B. (1996). Dump the cash, load on the praise. Personnel Journal, 75(7), 65-70.

Noe, R. A. (2009). Employee training and development (5th ed.). Boston, MA: McGraw-Hill.

Orpen, C. (1997). The effects of formal mentoring on employee work motivation, organizational commitment and job performance. The Learning Organization, 4(2), 53-60.

Panagiotakopoulos, A. (2013). The impact of employee learning on staff motivation in Greek small firms: The employees' perspective. Development and Learning in Organisations, 27(2), 13-15.

Pantouvakis, A., \& Bouranta, N. (201). The interrelationship between service features, job satisfaction and customer satisfaction: Evidence from the transport sector. TQM Journal, 25(2), 186-201.

Park, S. M. (2010). The effects of personnel reform systems on Georgia state employees' attitudes: An empirical analysis from a principal-agent theoretical perspective. Public Management Review, 12(3), 403-437.

Parvin, M. M., \& Kabir, N. M. M. (2011). Factors affecting employee job satisfaction of pharmaceutical sector. Australian Journal of Business and Management Research, 1(9), 113-123.

Pouliakas, K. (2010). Pay enough, don't pay too much or don't pay at all?, The impact of bonus intensity on job satisfaction. Kyklos, 63(4), 597-626.

Rabby, G. P. (2001). Motivation is response. Industrial and commercial training, 33(1), 26-28.

Rose, D. S., Sidle, S. D., \& Griffith, K. H. (2007). A penny for your thoughts: Monetary incentives improve response rates for company-sponsored employee surveys. Organizational Research Methods, 10, 225-240.

Rowley, J. (1996a). Motivation of staff in libraries. Library Management, 17(5), 31-35.

Rowley, J. (1996b). Motivation and academic staff in higher education. Quality Assurance in Education, 4(3), 11-16.

Rowold, J. (2007). The impact of personality on training-related aspects of motivation: Test of a longitudinal model. Human Resource Development Quarterly, 18(1), 9-31.

Saari, L. M., \& Judge, T. A. (2004). Employee attitudes and job satisfaction. Human Resource Management, 43(3), 395-407.

Sarkar, S., \& Huang, K. L. (2012). Do cultural groups differ in their attitudes towards unions Evidence from Indian and Taiwanese samples. Asian Business and Management, 11(4), 395-423.

Satyawadi, R., \& Ghosh, P. (2012). Motivation and work values in Indian public and private sector enterprises: A comparative study. International Journal of Human Resources Development and Management, 12(3), 237-253.

Schultz, D. S., \& Brabender, V. M. (2013). More challenges since Wikipedia: The effects of exposure to internet information about the rorschach on selected comprehensive system variables. Journal of Personality Assessment, 95(2), 149-158.

Seyler, D. L., Holton, E. F, I. I. I., Bates, R. A., Burnett, M. F., \& Carvalho, M. A. (1998). Factors affecting motivation to transfer training. International Journal of Training and Development, 2(1), 2-16.

Smith and Rupp. (2003). An examination of emerging strategy and sales performance: Motivation, chaotic change and organizational structure. Marketing Intelligence and Planning, 21(3), 156-167.

Steidle, A., Gockel, C., \& Werth, L. (2013). Growth or security? Regulatory focus determines work priorities. Management Research Review, 36(2), 173-182.

Swift, P. E., \& Hwang, A. (2013). The impact of affective and cognitive trust on knowledge sharing and organizational learning. Learning Organization, 20(1), 20-37.

Syed, A. A. S. G., Anka, L. M., Jamali, M. B., \& Shaikh, F. M. (2012). Motivation as a tool for effective staff productivity in the public sector: A case study of raw materials research and development council of Nigeria. Asian Social Science, 8(11), 85-95.

Szczepanowski, R., Traczyk, J., Wierzchoń, M., \& Cleeremans, A. (2013). The perception of visual emotion: Comparing different measures of awareness. Consciousness and Cognition, 22(1), 212-220. 
Tai, W. T. (2006). Effects of training framing, general self-efficacy and training motivation on trainees' training effectiveness. Personnel Review, 35(1), 51-65.

Tharenou, P. (2001). The relationship of training motivation to participation in training and development. Journal of Occupational and Organizational Psychology, 74(5), 599-621.

Tsai, W.-C., \& Tai, W. T. (2003). Perceived importance as a mediator of the relationship between training assignment and training motivation. Personnel Review, 32(2), 151-163.

Van Vianen, A. E. M., Dalhoeven, B. A. G. W., \& De Pater, I. E. (2011). Aging and training and development willingness: Employee and supervisor mindset. Journal of Organizational Behavior, $32,226-247$.

Vuori, V., \& Okkonen, J. (2012). Knowledge sharing motivational factors of using an intra-organizational social media platform. Journal of Knowledge Management, 16(4), 592-603.

Whitehill, B. V., \& McDonald, B. A. (1993). Improving learning persistence of military personnel by enhancing motivation in a technical training program. Simulation Gaming, 24(3), 294-313.

Wickramasinghe, V. (2009). Predictors of job satisfaction among IT graduates in offshore Outsourced IT firms. Personnel Review, 38(4), 413-431.

Wiley, C. (1997). What motivates employees according to over 40 years of motivation surveys. International Journal of Manpower, 18(3), 263-280.

Williams, H. (2013). Achieving supply chain utopia: Companies need to priorities investing in people. Development and Learning in Organizations, 27(2), 16-19.

Williams, E. S., Konrad, T. R., Linzer, M., McMurray, J., Pathman, D. E., Gerrity, M., et al. (2003). Refining the measurement of physician job satisfaction: Results from the physician work life survey. Medical Care, 37(11), 1140-1154.

Yamamoto, H. (2013). The relationship between employees' perceptions of human resource management and their retention: From the viewpoint of attitudes toward job specialties. International Journal of Human Resource Management, 24(4), 747-767.

Yang, Y.-F., \& Islam, M. (2012). The influence of transformational leadership on job satisfaction: The balanced scorecard perspective. Journal of Accounting and Organizational Change, 8(3), 386-402.

Zhang, H. Q., \& Wu, E. (2004). Human resources issues facing the hotel and travel industry in China. International Journal of Contemporary Hospitality Management, 16(7), 424-428. 